\title{
Metabolism plays the key roles in Th cells differentiation
}

\author{
A. Hosseinzadeh ${ }^{1}$, S. Soukhtehzari' ${ }^{2}$, M. Ghaedi ${ }^{3}$, R. Mansouri ${ }^{1}$ \\ 'Department of Immunology, Faculty of Medicine, Shahid Sadoughi University of Medical Sciences, Safaieye, \\ Yazd/Iran; 'Department of Medical Biotechnology, Tarbiat Modarres University, Medical School, Tehran, Iran; \\ ${ }^{3}$ Department of Immunology, School of Public Health, Tehran University of Medical Sciences, Tehran, Iran.
}

\begin{abstract}
SUMMARY
The increasing rate of autoimmunity in recent decades cannot be related to only genetic instabilities and disorders. Diet can directly influence our health. Studies have shown that there is a relationship between nutritional elements and alteration in the immune system. Among immune cells, the function of T lymphocyte is important in directing immune response. $\mathrm{T} \mathrm{CD}^{+}$cells lead other immune cells to respond to pathogens by secreting cytokines. $\mathrm{HIV}^{+}$patients, who have largely lost their $\mathrm{T} \mathrm{CD} 4^{+}$cells, are susceptible to opportunistic infections, which do not normally affect healthy people. It seems that the metabolism of T cells is critical for their differentiation and their consequent functions. After activation, T cells need to undergo clonal expansion, which is a high energy-consuming process. Studies have shown that specific metabolites deprivation or their excess supply affects $\mathrm{T} \mathrm{CD} 4^{+}$cells subsets differentiation. Abnormal induction of subsets of $\mathrm{T} \mathrm{CD} 4^{+}$cells causes some autoimmunity reactions and hyper-sensitivity as well, which may result from imbalance of diet uptake. In this mini-review, we describe the findings about fatty acids, glucose, amino acids, and vitamins, which are effective in determining the fates of T CD4 ${ }^{+}$cells. These findings may help us uncover the role of diet in autoimmune diseases.
\end{abstract}

Key words: T helper cells; metabolism; mTOR, autoimmunity.

Reumatismo, 2016; 68 (4): 176-182

\section{INTRODUCTION}

mmunometabolism has become an attractive field for both immunologists and nutritionists over the last decades. Nutritional research has shown that specific diets can increase the longevity of some patients with autoimmune conditions (14). From the immunological point of view, the mechanisms involved are not fully understood. In recent years, immunological research has focused on revealing these mechanisms. Meanwhile, there is the question of whether and how immunometabolism and autoimmunity are linked to each other.

Autoimmunity diseases occur when the immune system attacks self-antigens or when it cannot regulate the intensity of immune responses. The reasons for autoimmunity disorders are not clear enough yet. The most common theory is that genetic factors along with environmental factors like diet, as one of the most influential factors, play critical roles. Moreover, nutritional elements (whether micro or macro) have well-known effects on the immune system. Excess supply or deficiency of specific metabolites can also have considerable impact on the functions of the immune system (57). Among various immune cells, $\mathrm{T} \mathrm{CD} 4^{+}$ cells play a critical role. There is a body of evidence, which states that metabolites have enormous effects on T CD4 ${ }^{+}$cells and alter their functions resulting in autoimmune diseases.

In this paper, only the aspect of $\mathrm{T} \mathrm{CD} 4^{+}$cells metabolism is reviewed. Thereafter, the metabolic status of $\mathrm{T} \mathrm{CD}^{+}{ }^{+}$cells is described to evaluate the link between the immune system and metabolism. Also, some metabolic regulating molecules like mTOR and its function in T CD4 $4^{+}$cells will be introduced. Several studies have shown that mTOR plays an undeniable role in the fate of T $\mathrm{CD}^{+}{ }^{+}$cells. Different signals, including metabolic signals, which affect mTOR activity are discussed. 


\section{THE ROLE OF T CD4+ LYMPHOCYTES IN THE IMMUNE SYSTEM}

Among acquired immune cells, T lymphocytes play a critical role in proper immune response. $\mathrm{T}$ lymphocytes are divided into $\mathrm{T}$ helper $\left(\mathrm{T} \mathrm{CD}^{+}\right)$and $\mathrm{T}$ cytotoxic $\left(\mathrm{T} \mathrm{CD}^{+}\right)$ with different functions. $\mathrm{T} \mathrm{CD} 4^{+}$cells lead other immune cells, i.e., B lymphocytes and monocytes, to respond to pathogens by secreting cytokines. On the other hand, T $\mathrm{CD} 8{ }^{+}$cells kill target cells in a cell to cell manner. $\mathrm{T} \mathrm{CD} 8^{+}$cells are important in cellular immune response, while $\mathrm{T} \mathrm{CD} 4^{+}$cells functions are mainly mediated indirectly by arranging other immune cells.

$\mathrm{T} \mathrm{CD}^{+}$cells are classified in $\mathrm{T}$ effector subsets including: Th1, Th2, Th17 (Teff), and $\mathrm{T}$ regulatory (Treg) subsets. Th1 cells secrete IFN- $\gamma$ and active monocytes, while Th17 secretes IL-17. These subsets respond to intracellular pathogens. Th2 cells secrete IL-4 and IL-5, which eradicate extracellular pathogens like fungi and parasites. Th2 cells also are involved in hyper-sensitivity reactions. All these subsets protect against widespread pathogens. Treg cells are unique in their function. After a primary immune response, the immune system returns to the pre- activation situation.

$\mathrm{T} \mathrm{CD} 4^{+}$cells malfunction may lead either to susceptibility to infections and cancers, or it may cause self-antigen response, which results in autoimmunity. The $\mathrm{T} \mathrm{CD} 4^{+}$cells function is clear in some autoimmune diseases like rheumatoid arthritis (RA), multiple sclerosis (MS), inflammatory bowel disease (IBD) and psoriasis, whilst it is under investigation in other diseases.

Specifically, studies show that Th17 are involved in RA pathogenesis and Treg and Breg cells are also down-regulated. Thus, in these patients, Treg therapy may be a potential strategy (8). Not only is the use of immunosuppressant drugs like rapamycin a therapeutic candidate, recognition of $\mathrm{T}$ $\mathrm{CD}^{+}$cells' metabolic demands may also help find alternative ways of treatment. Imagine a specific formulated medium that is able to induce Treg cells from patients' PBMC, or a specific diet which suppresses clinical manifestation of the diseases (9). These ideas are not just a daydream; some nutritional and immunological studies have been designed to find out the role of different metabolites on clinical features of autoimmune diseases. But the blind spot of these studies is that they do not investigate differentials between sexes, races, and other aspects. In fact, it seems that there is a long road to be travelled before achieving clinic-based data in this category.

White et al. revealed that the level of vitamin D is negatively correlated with incidence of MS (2-4, 10), RA, type I diabetes, and psoriasis (2). Fish oil reduces chronic inflammation in IBD (11), RA, psoriasis, and asthma (12) patients. It is hypothesized that omega-3 PUFAs are Th1 antagonist (11).

\section{UNIQUE FEATURES OF T CD4+ CELLS METABOLISM}

$\mathrm{T} \mathrm{CD} 4^{+}$cells are potentially able to arrange an innate and acquired immune system. They secrete a wide range of cytokines and regulate the switching of the immune response $(13,14)$. Moreover, $\mathrm{T} \mathrm{CD}^{+}{ }^{+}$cells play key roles in the pathogenesis of some autoimmunities. Therefore, if $\mathrm{T} \mathrm{CD} 4^{+}$cells function improperly, they can imperil the body health.

Immune responses are anabolic reactions, the initiation of which is a highly energyconsuming process. Before the activation of $\mathrm{T} \mathrm{CD} 4^{+}$cells, they present no activity at resting phase. Their basic metabolism is represented by catabolism (15). During the resting phase, $\mathrm{T} \mathrm{CD} 4^{+}$cells obtain their energy through autophagy and lipid oxidation $(9,16)$. Soon after activation, T $\mathrm{CD} 4^{+}$cells undergo a metabolic reprogramming. They switch catabolic metabolisms to anabolic ones (17). Anabolism is a required process for DNA, protein, and lipid synthesis, all of which are essential molecules for cell growth and proliferation. In fact, $\mathrm{T} \mathrm{CD} 4^{+}$cells like cancer cells need to rapidly undergo a clonal expansion. Hence, they both need high amounts of energy in a short time and have to use a new strategy. In 1924, Otto Warburg reported that 
cancer cells utilize glycolysis to supply energy while normal cells exploit oxidative phosphorylation. This specific metabolism is called the Warburg effect, which is used by activated $\mathrm{T} \mathrm{CD} 4^{+}$cells (18-22). At a first glance, this strategy does not seem logical. However, when cells undergo mass proliferation to clonal growth (like cancer cells or activated $\mathrm{T} \mathrm{CD} 4^{+}$cells), they need not only energy, but also intense synthesis of proteins, DNA and lipid building blocks $(16,17)$. Although glycolysis provides less ATP compared to oxidative phosphorylation, intermediate byproducts of glycolysis are utilized as substrates for protein, DNA, and lipid biogenesis. After completing the step-by-step reasoning of similar metabolic programs in cancer and $\mathrm{T} \mathrm{CD} 4^{+}$cells, could it be concluded that the same molecules control this strategy?

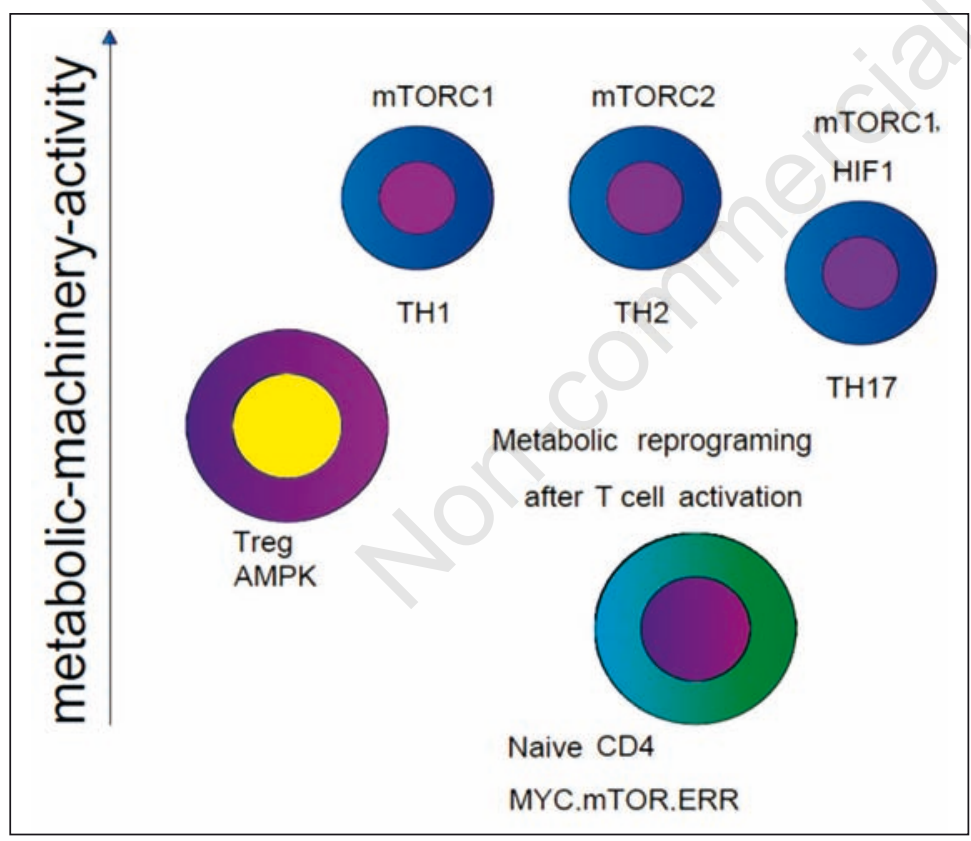

Figure 1 - Metabolic differences between T CD4+ subsets. After activation, all differentiated $\mathrm{T} \mathrm{CD4}{ }^{+}$subtypes change their metabolic program. This change is accompanied by an increase of metabolic demands. The important point is that all differentiated subtypes show more metabolic machinery activation compared to basic metabolism of naïve T CD4+. But among them, Treg cells are specific. Th1, Th2 and Th17 are initially glycolytic while Treg cells metabolism relies on lipid oxidation. Moreover, while Treg cells are less active than the others, they are more active than naïve $T$ cells. The difference between them seems logical, because these cells get activated in different immune microenvironments and their functions are also different.

\section{T CD4+CELLS ACTIVATION RESULTS IN mTOR ACTIVATION}

After activation of $\mathrm{T} \mathrm{CD} 4^{+}$cells, according to variable signals of immunological microenvironment, they differentiate into Teff or Treg subsets. As shown, Teff subsets (Th1, Th2 and Th17) and Treg have different metabolisms (23-29) (Figure 1).

The mechanistic target of rapamycin (mTOR) is a conserved molecule from yeast to humans. mTOR is one of the important kinases which regulate cell growth and controls cell metabolism in response to environmental signals. In mammalian cells, mTOR is encoded as a single gene. The mTOR protein consists of two complexes: mTORC1 and mTORC2 (30). These complexes play distinct roles. mTORC1 regulates autophagy, transcription, translation, and ribosome biogenesis. mTORC2 regulates cell survival. Also, cytoskeleton organization mTORC1 is the down-stream of AKt while mTORC2 is the up-stream of AKt. mTOR is a key sensor of cell energy status and nutrition. In $\mathrm{T} \mathrm{CD} 4^{+}$cells, mTOR is activated by IL-2 and/or CD28 signaling $(31,32)$. Its activity is also controlled by metabolic signals. Consequently, both immunological and metabolic signals control mTOR activity. It is not surprising that metabolic status can affect $\mathrm{T} \mathrm{CD} 4^{+}$cell function since the same molecules or pathways like mTOR are involved in immunological and metabolic signals.

For instance, CD28 signaling cascades can finally activate mTOR (17). On the other hand, an increasing level of intracellular amino acids like glutamine also activates the mTOR cascade (33).

An interesting point is that even in the presence of CD28 signaling, rapamycin-treated $\mathrm{T} \mathrm{CD} 4^{+}$cells can become anergic.

In summary, it can be concluded that mTOR plays a central role in the fate of $T$ $\mathrm{CD} 4^{+}$cells. mTOR activation results in $\mathrm{T}$ $\mathrm{CD} 4^{+}$cells differentiation to Teff subsets. mTOR suppression by pharmacological or metabolic agents and $\mathrm{T} \mathrm{CD} 4^{+}$cells activation may impair anergy or Treg induction (34) (Figure 2). 


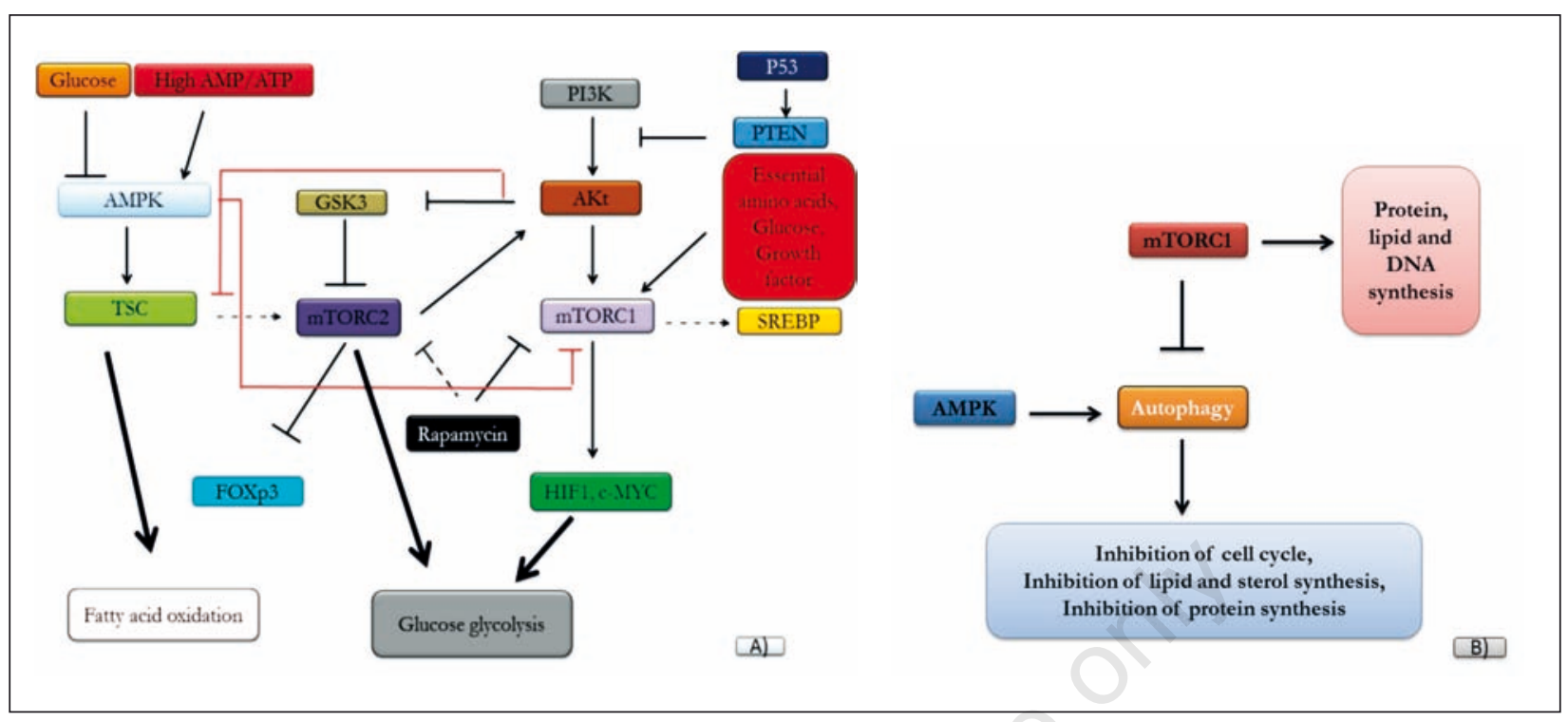

Figure 2 - Important cellular pathways in different T CD4+ cells. A) PI3K/AKt/mTOR pathway. By mTOR activation in T $\mathrm{CD}^{+}$cells, this pathway facilitates glycolysis by its enzymes and glucose transporters up-regulation. Hence, T CD4 ${ }^{+}$ cells glucose uptake will increase. Glucose degradation in glycolysis yields 2 ATP and supplies DNA, proteins and lipids building blocks. PTEN as a tumor suppressor acts on the PI3K/AKt/mTOR pathway directly. The AMPK/TSC pathway finally promotes lipid oxidation. In the presence of oxygen, this pathway is preferred by most normal cells because its ATP yield is high (36 ATP) compared to glycolysis. B) AMPK and mTOR have contrasting effects on T CD4+ cell fate.

Metabolism of cancer cells like Teff cells is glycolytic. mTOR activation results in the promotion of glycolysis in both cells. It should be noted that specific metabolites can regulate mTOR activity and consequently the fate of $\mathrm{T} \mathrm{CD} 4^{+}$cells (Table I) $(10,15,19,35-46)$.

As shown in Table I, several studies have been devised to find the mechanisms involved in determining $\mathrm{T} \mathrm{CD} 4^{+}$cells differentiations, and factors like fatty acids and vitamins have been evaluated. Fatty acids are one of the most important elements in the diet.

The level of fatty acids intake or their ratio, for instance omega 6/omega 3, plays a critical role in body health. Palmitic, linoleic, stearic, oleic, and arachidonic acids contain $80 \%$ of phosphatidylcholine in human plasma $(47,48)$. The possibility exists that these fatty acids influence our immune system like other nutritional elements. Besides, previous studies were not conclusive about the role of SCFA, SFA or unsaturated fatty acid (USFA) on T CD4 ${ }^{+}$cell differentiation.

\section{FATTY ACIDS EFFECTS ON T CD4+ DIFFERENTIATION}

The effect of fatty acid on T CD4+ is not fully understood yet. Some studies have suggested that short chain fatty acids (SCFA), like acetate, propionate and butyrate $(\mathrm{C} 2$, $\mathrm{C} 3$ and $\mathrm{C} 4$ respectively) can induce effector (39) and regulatory T CD4 ${ }^{+}$cell subsets differentiation $(39,42)$, whereas long chain fatty acids have different effects on $\mathrm{T} \mathrm{CD} 4^{+}$ cells. Omega 3 poly unsaturated fatty acids (n-3 PUFA) are TH1 and Th17 antagonist (1) and decreased the number of cells in some osteoarthritis models (1). Furthermore, n-3 PUFA can suppress T cell function and increase Treg cells number. One possible mechanism that explains the effect of n-3 PUFA on T CD4 ${ }^{+}$is the involvement of PPAR receptors (49).

Fatty acid synthesis also plays an important role in $\mathrm{T} \mathrm{CD}^{+}$differentiation. Studies have shown that inhibition of enzymes, which are engaged in fatty acid synthesis, results in Treg differentiation (50). Even at the TH17-polarizing condition, inhibition 
Table I - Different metabolites effect on immune system.

\begin{tabular}{|c|c|c|c|c|}
\hline Metabolite & Results & Possible mechanism & Conclusion & Ref \\
\hline Vitamin A & Treg induction & $\begin{array}{l}\text { Impairing } T \text { cell proliferation } \\
\text { and activation }\end{array}$ & $\begin{array}{l}\text { Vitamin A plus TGF can } \\
\text { induce Treg }\end{array}$ & Benson et al. (35) \\
\hline $\begin{array}{l}\text { Palmitic and oleic } \\
\text { acid }\end{array}$ & Treg induction & $\begin{array}{l}\text { mTOR suppression } \\
\text { AMPK activation }\end{array}$ & $\begin{array}{l}\text { Palmitic/oleic acid can induce } \\
\text { Treg in vitro }\end{array}$ & Michalek et al. (15) \\
\hline Glucose (depletion) & $\begin{array}{l}\text { Th17 inhibition } \\
\text { Treg induction }\end{array}$ & $\begin{array}{l}\text { mTOR/HIF activity } \\
\text { suppression }\end{array}$ & $\begin{array}{l}\text { Glucose deprivation inhibits Th17 } \\
\text { and induces Treg }\end{array}$ & Shi et al. (19) \\
\hline Glucose & IL-17 production & NFkB expression induction & $\begin{array}{l}\text { High glucose induces IL-17 } \\
\text { production }\end{array}$ & Kumar et al. (36) \\
\hline Oxygen & Th17 induction & Increasing mTOR activity & $5 \% \mathrm{O}_{2}$ induces $\mathrm{Th} 17$ & Ikejiri et al. (37) \\
\hline $\mathrm{NaCl}$ & Th17 induction & MAPK activation & High $\mathrm{NaCl}$ induces Th17 in vitro & $\begin{array}{l}\text { Kleinewietfeld et al. } \\
\text { (10) }\end{array}$ \\
\hline Palmitic acid & $\begin{array}{l}\text { IL- } 6 \text { and TNF- } \alpha \text { induction } \\
\text { of expression }\end{array}$ & NFkB activation & $\begin{array}{l}\text { Palmitic acid can induce } \\
\text { pro-inflammatory cytokines }\end{array}$ & Ajuwon et al. (38) \\
\hline $\begin{array}{l}\text { Acetate Propionate } \\
\text { Butyrate (SCFA) }\end{array}$ & Teff and Treg induction & mTOR regulation & $\begin{array}{l}\text { SCFA fatty acid can effect } \\
\text { effector and regulatory subsets } \\
\text { differentiation }\end{array}$ & Park et al. (39) \\
\hline Omega-3 PUFA & $\begin{array}{l}\text { Th1 and Th2 suppression } \\
\text { and Treg induction }\end{array}$ & $\begin{array}{l}\text { Inhibition of pro-inflammatory } \\
\text { factors production like TNF- } \alpha\end{array}$ & $\begin{array}{l}\text { Fish oil can play anti allergic } \\
\text { role }\end{array}$ & Han et al. (40) \\
\hline Folic acid & Treg maintenance & Not clear & $\begin{array}{l}\text { Dietary folic acid is needed } \\
\text { for colon Treg maintenance } \\
\text { and survival }\end{array}$ & Kinoshita et al. (41) \\
\hline SCFA & Treg induction & $\begin{array}{l}\text { SCFA can inhibit HDAC } \\
\text { activity }\end{array}$ & $\begin{array}{l}\text { SCFA show anti-inflammatory } \\
\text { role }\end{array}$ & Smith et al. (42) \\
\hline SFA & $\begin{array}{l}\text { TNF- } \alpha \text { and COX-2 } \\
\text { induction in } M Q \text { cells }\end{array}$ & TLR2 and TLR4 activation & $\begin{array}{l}\text { SFA can active MQ cells } \\
\text { in pro-inflammatory manner }\end{array}$ & Huang et al. (43) \\
\hline Acetate Propionate & Impair Th2 differentiation & $\begin{array}{l}\text { SCFA can influence DCs } \\
\text { hence they can't active Th2 }\end{array}$ & $\begin{array}{l}\text { SCFA by Th2 inhibition may } \\
\text { can improve allergy }\end{array}$ & Trompett et al. (44) \\
\hline $\begin{array}{l}\text { Fish oil plus } \\
\text { astaxanthin }\end{array}$ & $\begin{array}{l}\text { Decreasing } T \text { cell } \\
\text { proliferation decreasing in } \\
\mathrm{H}_{2} \mathrm{O}_{2} \text { production }\end{array}$ & MAPK inhibition & $\begin{array}{l}\text { Fish oil and astaxanthindamp } \\
\mathrm{T} \text { cell function }\end{array}$ & Otton et al. (45) \\
\hline Butyrate & $\begin{array}{l}\text { Induction of } \mathrm{T} \mathrm{CD4}^{+} \\
\text {anergy }\end{array}$ & Butyrate inhibits HDAC activity & $\begin{array}{l}\text { Butyrate induce functional } \\
\text { un-responsiveness in T CD4+ }\end{array}$ & Fontenelle et al. (46) \\
\hline
\end{tabular}

HIF1: Hypoxia-inducible factor is a transcription factor, which is sensitive to decreased $\mathrm{O}_{2}$ in cell environment, NFkB: nuclear factor kappa-light-chain-enhancer of activated $B$ cells is a controller of DNA transcription, MAPK: Mitogen-activated protein kinase is a kinase, which is involved in proliferation of cells, SCFA: short chain F. A, PUFA: poly unsaturated F.A, HDAC: Histone deacetylases, SFA: saturated F.A, MQ: macrophage and DCs: dendritic cells.

of fatty acid synthesis prevents TH17 differentiation (51).

It can be concluded that n-3 PUFAs have an anti-inflammatory effect (43) on the immune system. In contrast, saturated fatty acids have a pro-inflammatory impact on the immune system $(52,53)$. The effect of mono saturated fatty acid (MFA) on the immune system is not clearly demonstrated. Omega 6 or omega 9 MFA have different or even opposite effects on the immune system (54), a finding that may be due to the type of study design, in vivo or in vitro. Adding fatty acids to T cell or PBMC cell culture may have divergent results on $\mathrm{T}$ $\mathrm{CD}^{+}{ }^{+}$differentiation. The level of micro and macro elements and their ratio (glucose, proteins or fatty acid) are also crucial. Results have shown that if adequate glucose is present in cell culture as an energy source, fatty acids are not consumed. Previous studies have shown that even with the presence of sufficient amounts of alternative energy sources, $\mathrm{T} C D 4^{+}$cells prefer 
to use glucose. Although Treg cells rely on lipid oxidation, the addition of only fatty acid to the cell culture is not sufficient for Treg induction. However, the preferential energy source for $\mathrm{T} \mathrm{CD} 4^{+}$cells is demonstrated to be glucose (55). Hence, $\mathrm{T}$ $\mathrm{CD} 4^{+}$cells need to be deprived of glucose to enforce the consumption of fatty acids. It is necessary to check all nutritional elements precisely in the cell culture and then add or remove specific metabolites.

\section{CONCLUSIONS}

In the past few years, researchers focused strongly on immunometabolism. Current scientific evidence suggests that nutritional elements can potentially influence the immune system and the general body health as well. Metabolic and immunological signals can affect the differentiation of $\mathrm{T}$ $\mathrm{CD} 4^{+}$cells like cancer cells. Differentiated $\mathrm{T} \mathrm{CD} 4^{+}$subsets have various metabolic programs. Among them, only Treg depends on lipid oxidation for differentiation. It is important to note that for in vitro Treg induction alongside the addition of fatty acid, glucose deprivation is necessary.

\section{REFERENCES}

1. Monk JM, Hou TY, Turk HF, et al. Dietary n-3 polyunsaturated fatty acids (PUFA) decrease obesity-associated Th17 cell-mediated inflammation during colitis. PLoS One. 2012; 7: e49739.

2. White JH. Vitamin D metabolism and signaling in the immune system. Rev Endocr Metab Disords. 2012; 13: 21-9.

3. Smolders J, Damoiseaux J, Menheere P, Hupperts R. Vitamin D as an immune modulator in multiple sclerosis, a review. J Neuroimmunol. 2008; 194: 7-17.

4. Manzel A, Muller DN, Hafler DA, et al. Role of "Western diet" in inflammatory autoimmune diseases. Curr Allergy Asthma Rep. 2014; 14: 1-8.

5. Monk JM, Kim W, Callaway E, et al. Immunomodulatory action of dietary fish oil and targeted deletion of intestinal epithelial cell PPAR $\delta$ in inflammation-induced colon carcinogenesis. Am J Physiol Gastrointest Liver Physiol. 2012; 302: G153-G67.

6. Hua J, Ma X, Webb T, et al. Dietary fatty acids modulate antigen presentation to hepatic NKT cells in nonalcoholic fatty liver disease. J Lipid Res. 2010; 51: 1696-703.

7. Winnik S, Lohmann C, Richter EK, et al. Di- etary $\alpha$-linolenic acid diminishes experimental atherogenesis and restricts T cell-driven inflammation. Eur Heart J. 2011: ehq501.

8. Burmester GR, Feist E, Dörner T. Emerging cell and cytokine targets in rheumatoid arthritis. Nat Rev Rheumatol. 2014; 10: 77-88.

9. O’Sullivan D, Pearce EL. Targeting T cell metabolism for therapy. Trends Immunol. 2015; 36: 71-80.

10. Kleinewietfeld M, Manzel A, Titze J, et al. Sodium chloride drives autoimmune disease by the induction of pathogenic TH17 cells. Nature. 2013; 496: 518-22.

11. Monk JM, Hou TY, Turk HF, et al. Dietary n-3 polyunsaturated fatty acids (PUFA) decrease obesity-associated Th17 cell-mediated inflammation during colitis. PLoS One. 2012; 7 : e49739.

12. Jaudszus A, Gruen M, Watzl B, et al. Evaluation of suppressive and pro-resolving effects of EPA and DHA in human primary monocytes and Thelper cells. J Lipid Res. 2013; 54: 923-35.

13. Baranowski M, Enns J, Blewett H, et al. Dietary flaxseed oil reduces adipocyte size, adipose monocyte chemoattractant protein- 1 levels and T-cell infiltration in obese, insulin-resistant rats. Cytokine. 2012; 59: 382-91.

14. Riley JL, June CH, Blazar BR. Human T regulatory cell therapy: take a billion or so and call me in the morning. Immunity. 2009; 30: 656-65.

15. Michalek RD, Gerriets VA, Jacobs SR, et al. Cutting edge: distinct glycolytic and lipid oxidative metabolic programs are essential for effector and regulatory CD4+ T cell subsets. J Immunol. 2011; 186: 3299-303.

16. Rathmell JC. Metabolism and autophagy in the immune system: immunometabolism comes of age. Immunol Rev. 2012; 249: 5-13.

17. Powell JD, Delgoffe GM. The mammalian target of rapamycin: linking T cell differentiation, function, and metabolism. Immunity. 2010; 33: 301-11.

18. Gerriets VA, Rathmell JC. Metabolic pathways in $\mathrm{T}$ cell fate and function. Trends Immunol. 2012; 33: 168-73.

19. Shi LZ, Wang R, Huang G, et al. HIF1 $\alpha-$ dependent glycolytic pathway orchestrates a metabolic checkpoint for the differentiation of TH17 and Treg cells. J Exp Med. 2011; 208: 1367-76.

20. Marelli-Berg FM, Fu H, Mauro C. Molecular mechanisms of metabolic reprogramming in proliferating cells: implications for T-cell-mediated immunity. Immunology. 2012; 136: 363-9.

21. Yang K, Chi H. mTOR and metabolic pathways in $\mathrm{T}$ cell quiescence and functional activation. Semin Immunol. 2012; 24: 421-8.

22. Pollizzi KN, Powell JD. Regulation of T cells by mTOR: the known knowns and the known unknowns. Trends Immunol. 2015; 36: 13-20.

23. Wang R, Green DR. Metabolic checkpoints in activated T cells. Nat Immunol. 2012; 13: 90715. 
24. Yang Z, Matteson EL, Goronzy JJ, Weyand CM. T-cell metabolism in autoimmune disease. Arthritis Res Ther. 2015; 17: 29.

25. Semenza GL. Hypoxia-inducible factors in physiology and medicine. Cell. 2012; 148: 399-408.

26. Coomes SM, Pelly VS, Wilson MS. Plasticity within the $\alpha \beta+\mathrm{CD} 4+\mathrm{T}$-cell lineage: when, how and what for? Open Biol. 2013; 3: 120157.

27. Delgoffe GM, Powell JD. Sugar, fat, and protein: new insights into what T cells crave. Curr Opin Immunol. 2015; 33: 49-54.

28. Josefowicz SZ, Lu L-F, Rudensky AY. Regulatory T cells: mechanisms of differentiation and function. Annu Rev Immunol. 2012; 30: 531-64.

29. Xu X, Ye L, Araki K, Ahmed R. mTOR, linking metabolism and immunity. Semin Immunol. 2012; 24: 429-35.

30. Araki K, Ellebedy AH, Ahmed R. TOR in the immune system. Curr Opin Cell Biol. 2011; 23: 707-15.

31. Mondino A, Mueller DL. mTOR at the crossroads of $\mathrm{T}$ cell proliferation and tolerance. Semin Immunol. 2007; 19: 162-72.

32. Vignot S, Faivre S, Aguirre D, Raymond E. mTOR-targeted therapy of cancer with rapamycin derivatives. Ann Oncol. 2005; 16: 525-37.

33. Ramsay G, Cantrell D. Environmental and metabolic sensors that control T cell biology. Front Immunol. 2015; 6.

34. O'Neill LA, Hardie DG. Metabolism of inflammation limited by AMPK and pseudo-starvation. Nature. 2013; 493: 346-55.

35. Benson MJ, Pino-Lagos K, Rosemblatt $M$, Noelle RJ. All-trans retinoic acid mediates enhanced $\mathrm{T}$ reg cell growth, differentiation, and gut homing in the face of high levels of co-stimulation. J Exp Med. 2007; 204: 1765-74.

36. Kumar P, Natarajan K, Shanmugam N. High glucose driven expression of pro-inflammatory cytokine and chemokine genes in lymphocytes: molecular mechanisms of IL-17 family gene expression. Cell Signal. 2014; 26: 528-39.

37. Ikejiri A, Nagai S, Goda N, et al. Dynamic regulation of Th17 differentiation by oxygen concentrations. Int Immunol. 2012; 24: 137-46.

38. Ajuwon KM, Spurlock ME. Palmitate activates the NF-kappaB transcription factor and induces IL-6 and TNFalpha expression in 3T3-L1 adipocytes. J Nutr. 2005; 135: 1841-6.

39. Park J, Kim M, Kang S, et al. Short-chain fatty acids induce both effector and regulatory $\mathrm{T}$ cells by suppression of histone deacetylases and regulation of the mTOR-S6K pathway. Mucosal Immunol. 2015; 8: 80-93.

40. Han S-C, Kang G-J, Ko Y-J, Kang H-K, Moon S-W, Ann Y-S, et al. Fermented fish oil suppresses $T$ helper $1 / 2$ cell response in a mouse model of atopic dermatitis via generation of CD4+ CD25+ Foxp3+ T cells. BMC Immunol. 2012; 13: 44

41. Kinoshita M, Kayama H, Kusu T, Yamaguchi T, Kunisawa J, Kiyono H, et al. Dietary folic acid promotes survival of Foxp3+ regulatory T cells in the colon. J Immunol. 2012; 189: 2869-78.

42. Smith PM, Howitt MR, Panikov N, et al. The microbial metabolites, short-chain fatty acids, regulate colonic Treg cell homeostasis. Science. 2013; 341: 569-73.

43. Huang S, Rutkowsky JM, Snodgrass RG, et al. Saturated fatty acids activate TLR-mediated proinflammatory signaling pathways. J Lipid Res. 2012; 53: 2002-13.

44. Trompette A, Gollwitzer ES, Yadava K, et al. Gut microbiota metabolism of dietary fiber influences allergic airway disease and hematopoiesis. Nat Med. 2014; 20: 159-66.

45. Otton R, Marin DP, Bolin AP, et al. Combined fish oil and astaxanthin supplementation modulates rat lymphocyte function. Eur J Nutr. 2012; 51: 707-18.

46. Fontenelle B, Gilbert K. n-butyrate anergized effector $\mathrm{CD} 4+\mathrm{T}$ cells independent of regulatory $\mathrm{T}$ cell generation or activity. Scand J Immunol. 2012; 76: 457-63.

47. Kremmyda L-S, Tvrzicka E, Stankova B, Zak A. Fatty acids as biocompounds: Their role in human metabolism, health and disease-a review. Part 2: Fatty acid physiological roles and applications in human health and disease. Biomed Pap. 2011; 155: 195-218.

48. Tvrzicka E, Kremmyda L-S, Stankova B, Zak A. Fatty acids as biocompounds: their role in human metabolism, health and disease-a review. Part 1: classification, dietary sources and biological functions. Biomed Pap. 2011; 155: 117-30.

49. Berger H, Végran F, Chikh M, et al. SOCS3 Transactivation by PPAR $\gamma$ Prevents IL-17Driven Cancer Growth. Cancer Res. 2013; 73: 3578-90.

50. Eleftheriadis T, Pissas G, Antoniadi G, et al. Indoleamine 2, 3-dioxygenase depletes tryptophan, activates general control non-derepressible $2 \mathrm{ki}$ nase and down-regulates key enzymes involved in fatty acid synthesis in primary human CD4+ T cells. Immunology. 2015; 146: 292-300.

51. O'Sullivan D, Pearce EL. Fatty acid synthesis tips the TH17-Treg cell balance. Nat Med. 2014; 20: 1235-6.

52. Kunisawa J, Hashimoto E, Inoue A, et al. Regulation of intestinal $\operatorname{IgA}$ responses by dietary palmitic acid and its metabolism. J Immunol. 2014; 193: 1666-71.

53. Ajuwon KM, Spurlock ME. Palmitate activates the NF- $\kappa \mathrm{B}$ transcription factor and induces IL-6 and TNF $\alpha$ expression in 3T3-L1 adipocytes. J Nutr. 2005; 135: 1841-6.

54. Carrillo Pérez C, Cavia Camarero MdM, Alonso de la Torre S. Role of oleic acid in immune system; mechanism of action; a review. Nutr Hosp. 2012; 27: 978-990.

55. MacIver NJ, Jacobs SR, Wieman HL, et al. Glucose metabolism in lymphocytes is a regulated process with significant effects on immune cell function and survival. J J Leuko Biol. 2008; 84: 949-57. 